\title{
Community-acquired pneumonia
}

\author{
Nicola Mumoli MD, Marco Cei MD
}

See also practice article by Leis and Gold on page 559 and at www.cmaj.ca/lookup/doi/10.1503/cmaj.111143

Competing interests: None declared.

This article has been peer reviewed.

Affiliation: From the Department of Internal Medicine, Ospedale Civile Livorno, Livorno, Italy

Correspondence to: Dr. Nicola Mumoli, n.mumoli@usl6.toscana.it

CMAJ 2012. DOI:10.1503 /cmaj.111256


39-year-old man presented with fever $\left(38.7^{\circ} \mathrm{C}\right)$, cough and right chest pain on inspiration. His blood pressure was $125 / 75 \mathrm{~mm} \mathrm{Hg}$, heart rate was 88 beats/min, respiration was 20 breaths/min and oxygen saturation on room air was $94 \%$. Physical examination was remarkable only for crackles over the right upper lung field. Results of blood tests showed an elevated leukocyte count of 16.5 (normal 4.0-10.0) $\times 10^{9} / \mathrm{L}$ and were otherwise normal. Urinary testing for Legionella pneumophila and Streptococcus pneumoniae antigens was negative. Chest radiography showed pneumonia in the right upper lobe (Figure 1). Because the patient was at low risk for death (class I on the Pneumonia Severity Index), ${ }^{1}$ we prescribed oral penicillin and clarithromycin, and discharged the patient home. Follow-up chest radiography one month later showed that the consolidation had resolved (Appendix 1, available at www.cmaj.ca/lookup/suppl/doi :10.1503/cmaj.111256/-/DC1).

About 4 million instances of communityacquired pneumonia occur in the United States each year. It is one of the most common causes



Figure 1: Posteroanterior and lateral radiographs of the chest of a 39-year-old man with fever, cough and pleuritic chest pain showing consolidation in the right upper lobe. of death from infectious diseases worldwide. ${ }^{2}$ The precise diagnosis continues to be complex; at least $50 \%$ of causative pathogens remain unidentified, and all rigorous definitions of pneumonia require the finding of a pulmonary infiltrate on chest radiography. ${ }^{2}$ The initial antibiotic regimen should be chosen empirically to cover common typical and atypical pathogens. About $50 \%$ of patients with pneumonia can receive treatment outside of the hospital., ${ }^{2,3}$ The Pneumonia Severity Index is a validated prediction rule that identifies people with community-acquired pneumonia who are at low risk for death within 30 days of presentation. ${ }^{1}$ An alternative scale is the CURB-65, which takes into account confusion, urea level, respiration, blood pressure and age. ${ }^{4} \mathrm{~A}$ general rule of thumb is to admit patients with oxygen saturation under $92 \% .^{5}$

\section{References}

1. Fine MJ, Auble TE, Yealy DM, et al. A prediction rule to identify low-risk patients with community-acquired pneumonia. $N$ Engl J Med 1997;336:243-50.

2. Halm EA, Teirstein AS. Management of community-acquired pneumonia. N Engl J Med 2002;347:2039-45.

3. Mandell LA, Wunderink RG, Anzueto A, et al. Infectious Diseases Society of America/American Thoracic Society consensus guidelines on the management of community-acquired pneumonia in adults. Clin Infect Dis 2007;44(suppl 2):S27-72.

4. Chalmers JD, Singanayagam A, Akram AR, et al. Severity assessment tools for predicting mortality in hospitalised patients with community-acquired pneumonia. Systematic review and metaanalysis. Thorax 2010;65:878-83.

5. Majumdar SR, Eurich DT, Gamble JM, et al. Oxygen saturations less than $92 \%$ are associated with major adverse events in outpatients with pneumonia: a population-based cohort study. Clin Infect Dis 2011;52:325-31.

\section{Helpful resources}

- The Pneumonia Severity Index calculator is available online at http://pda.ahrq.gov/clinic /psi/psicalc.asp

- CURB-65 is available online at www.mdcalc .com/curb-65-severity-score-community -acquired-pneumonia 